\title{
Modelos de inserção internacional na África e as consequências internas e internacionais de sua aplicação
}

International models of insertion in Africa and internally and externally consequences of their application

\author{
Arcénio Francisco $\mathrm{Cuco}^{1}$ \\ Jefferson Pecori Viana ${ }^{2}$
}

\section{Resumo}

A ascensão de "novas" potências como China, Brasil e Índia suscita uma série de debates que visam entender a influência desses países na hierarquia de poder internacional. O objetivo é compreender como a África influencia a hierarquia internacional e caracterizar os diferentes modelos de inserção no continente africano, analisando a dupla face desse processo: as consequências tanto ao nível interno para os países africanos - em termos de autonomia e superação do subdesenvolvimento - quanto externamente para a hierarquia de poder no sistema internacional.

Palavras-chave: hierarquia internacional; modelos de inserção internacional; potências emergentes.

\begin{abstract}
The rise of Emerging Powers like China, Brazil and India raises a number of debates, in order to understand the influence of these countries in the international hierarchy of power. This article seeks to understand how Africa influences the international hierarchy and characterize the different integration models in Africa, analyzing the double aspect of this
\end{abstract}

\footnotetext{
${ }^{1}$ Doutorando em Ciência Política pela UFRGS. Mestre em Ciências Criminais pela Pontifícia Universidade Católica do Rio Grande do Sul. Integrante do Grupo de Pesquisa Direito à Verdade e à Memória e Justiça de Transição e do Grupo de Pesquisa em Criminologia (GEPCRIM). É membro do conselho editorial da revista Direito \& Inovação, do curso de Direito da URI/FW. Bolsista da Capes. País de residência: Brasil. E-mail: arcuco@yahoo.com.br.

${ }^{2}$ Doutorando em Estudos Estratégicos Internacionais pela UFRGS. Mestre em Relações Internacionais pela UFSC. Pesquisador do Núcleo de Estudos sobre os Brics (Nebrics/UFRGS) e do Centro de Estudos Sociopolíticos e Internacionais da América do Sul (Cespi-América do Sul/Unila). Integrante do Instituto de Estudos Latino-Americanos (Iela/UFSC). Bolsista da Capes. País de residência: Brasil. E-mail: jpreg8@hotmail.com.
} 
process: the consequences both internally for African countries - in terms of autonomy and overcoming underdevelopment - as externally to the hierarchy of power in the International System.

Keywords: international hierarchy; integration models; emerging powers

\section{INTRODUÇÃO}

A estrutura das relações internacionais até 1960 era dominada pela Europa ${ }^{3}$, sendo que, por exemplo, o mapa político da África e da Ásia foi traçado pelos alemães, ingleses e franceses, a partir do Ocidente. Até essa altura, as ações europeias nesses continentes não sofriam qualquer tipo de contestação (BARRACLOUGH, 1964). A partir daí, um sistema multilateral de equilíbrio, que tinha a Europa como centro, foi substituído por um sistema de bipolaridade global entre duas grandes potências: os Estados Unidos da América (EUA) e a União das Repúblicas Socialistas Soviéticas (URSS). Barraclough considera essa mudança verificada na posição política da Europa como a primeira grande revolução (que, para nós, teve uma segunda fase, que acontece com o fim do muro de Berlim e a consequente emergência e ascensão de novas potências internacionais, como China, Índia, Brasil, que desde finais da década de 1990 e princípios de 2000 vêm se afirmando como atores internacionais aos quais se deve prestar muita atenção) que alterou o caráter e as condições das relações internacionais.

Por que traçar esse marco histórico? Primeiro, porque o nosso foco é o continente africano, e a década de 1960 é considerada aquela das independências em África, uma vez que foi a partir desse período que muitos países africanos alcançaram suas independências territoriais. Segundo, porque a implantação de regimes de governação nesses países foi condicionada ao alinhamento ideológico a uma das duas superpotências,

\footnotetext{
${ }^{3}$ Ainda que economicamente os Estados Unidos já tivessem ocupado a posição de potência hegemônica desde fins da década de 1910, na esfera institucional da hegemonia, apenas a partir de 1945 é que os estadunidenses começaram a delinear suas características políticas e geopolíticas. Novas instituições como a UNCTAD (United Nations Conference on Trade and Development), uma articulação mais conjunta entre as instituições de Bretton Woods e a ajuda externa foram elementos que caracterizaram a primazia dos Estados Unidos. Por outro lado, entendendo esse contexto dentro da Guerra Fria, também a concorrência da União Soviética.
} 
o que acabou condicionando também os modelos de desenvolvimento implantados logo depois da proclamação da independência nesses países.

Como Frieden (2006) assinala, muitos países africanos se aliaram à URSS ou à China, apoiando de forma geral o caminho socialista mesmo que não replicando de forma taxativa os regimes soviético ou chinês. A adesão a esses países é explicada pela aliança oportunista com o "inimigo de seu inimigo", pois havia uma crença de que os regimes africanos de minoria branca contavam com apoio ativo ou passivo do Ocidente, por um lado. Por outro, era forte entre os países africanos a ideia de que o socialismo era apropriado às condições de subdesenvolvimento em que se encontravam mergulhados.

A verdade é que o caminho escolhido pelos países do continente africano trouxe mais dissabores do que o desenvolvimento a que muitos aspiravam, pois tais países se viram imersos numa guerra ideológica envolvendo EUA e URSS, o que resultou na morte de milhões de africanos. Houve uma politização de donativo que se consubstanciou no patrocínio a aliados estratégicos. 0 continente foi "infestado" por bilhões de dólares em armas para países como Angola, Moçambique, Etiópia, Somália e Libéria. Durante esse período, os EUA ignoraram princípios básicos como democracia e desenvolvimento, enfocando, de forma paroquial, a contenção do perigo do comunismo através de proteção, abastecimento militar e assistência financeira a ditadores brutais como o liberiano Samuel Doe, Mobutu Sese Seko, do Zaire, e Siad Barre, da Somália, em troca de suporte político e bases militares. (ADEBAJ0, 2013, p. 169).

Com o fim da Guerra Fria, os países africanos foram forçados pelo Ocidente, principalmente pelos EUA, a introduzir mudanças estruturais que lhes conferissem uma melhor inserção no mundo global. Essas mudanças passavam pelo afastamento do socialismo, pela aproximação ao capitalismo e pela introdução de democracias. A adoção dessas mudanças permitiria a esses países o acesso ao crédito das instituições de Bretton Woods (Fundo Monetário Internacional e Banco Mundial) para recuperarem suas economias. Entretanto, a despeito de obter ganhos significativos, essas mudanças, para Oliveira (2009), resultaram na degradação e na marginalização considerável do prestígio e do bem-estar do continente: 
A última década da Guerra Fria, apesar de ter sido particularmente visível e destrutiva, não fez muito para afetar a tendência geral para o empobrecimento da África e a ascensão do discurso de reformismo liberal fomentado pelo Ocidente. Porém, o final da Guerra Fria e da alternativa de patrocínio soviético, que permitira algum espaço de manobra aos regimes africanos, expôs a fragilidade do seu estatuto internacional e agravou a irrelevância crescente da África para o resto do mundo. (...) A dependência da África face ao sistema internacional cresceu em simultâneo com o seu declínio político e econômico, e isto apesar do interesse exterior para com o continente se ter reduzido progressivamente a alguns enclaves de interesses estratégicos, ou, em certos países, ter desaparecido completamente. A assimetria histórica das relações exteriores da África aprofundou-se de modo substancial (OLIVEIRA, 2009, p. 93).

Com a ascensão de "novas" potências como China, Brasil e Índia, uma nova configuração no plano internacional apresenta a África como, mais uma vez, o centro de disputa entre as novas e as tradicionais potências. Uma série de debates tem sido levantada, sobretudo para entender a influência desses países na ordem internacional, uma vez que, há menos de duas décadas, o centro das decisões internacionais estava no eixo Atlântico Norte, especialmente nos Estados Unidos e na Europa.

A ação das potências emergentes nos espaços territoriais, o que, via de regra, era dominado pelas grandes potências mundiais, tem sido criticada pela aplicação de modelos de inserção distintos daqueles modelos tradicionais colocados em marcha pelas potências ocidentais. Essa nova configuração internacional torna a África um campo de disputa entre potências tradicionais e aquelas em "ascensão", a partir da coexistência de vários modelos de inserção internacional.

Sendo assim, este ensaio se propõe a analisar a concorrência entre esses modelos de inserção, quer das potências emergentes, quer das potências tradicionais. 0 objetivo é caracterizar os diferentes modelos de inserção no continente africano e analisar a dupla face resultante desse processo: as consequências tanto ao nível interno, para os países africanos, quanto externamente, para a hierarquia do sistema internacional. 0 trabalho procurará trazer algumas consequências dos modelos de inserção das potências na África para o desenvolvimento africano - em termos de autonomia e superação do subdesenvolvimento - e para a hierarquia de poder no sistema internacional, que passa, 
inevitavelmente, pela compreensão profunda do papel desempenhado pelo continente africano nesse sistema.

\section{A HIERARQUIA DE PODER INTERNACIONAL E A INSERÇÃO INTERNACIONAL DO CONTINENTE AFRICANO}

Neste tópico, trataremos da maneira como o continente africano tem participado da configuração da hierarquia no sistema interestatal capitalista. 0 objetivo é demonstrar que as principais potências do sistema mundial sempre buscaram controlar e explorar a economia, a política e a cultura dos povos africanos de modo a criar capabilities $^{4}$ para o exercício e a busca de hegemonia internacional. Tangencialmente, tentaremos demonstrar que o aparelho econômico, político-administrativo e social montado para dominar o continente africano foi eficiente em sua empresa e que os problemas históricos (e atuais!) das sociedades africanas não são um "desvio" ou resultado da implantação inadequada das cartilhas de desenvolvimento capitalista, mas tão somente o outro lado da moeda do desenvolvimento desigual e combinado.

A hierarquia de poder internacional tem uma dupla face complementar e retroalimentadora: o sistema de Estados nacionais e o sistema capitalista, que constituem o que chamamos de sistema interestatal capitalista. Em adição a essas faces política e econômica, também se faz necessário compreender a sua ampliação em nível mundial ${ }^{5}$. A lógica expansionista do sistema capitalista impulsionou os Estados nacionais europeus ao "mais-além" da Europa, e o primeiro continente a receber a expansão capitalista foi a África, de modo que, ao tratar da hierarquia do poder internacional, estamos tratando da própria inserção internacional do continente africano na economia-mundo capitalista (HOPKINS; WALLERSTEIN, 1987).

\footnotetext{
${ }^{4}$ Waltz (1979) aborda como as capabilities dos Estados influenciam os vários tipos possíveis de equilíbrio da política internacional.

${ }^{5}$ É da interação do poder político e do poder do dinheiro que emergirá esse sistema mundial, que será explicado através do signo da constante busca pela hegemonia entre Estados-potências, cuja realização será a principal tendência que caracteriza a evolução do sistema interestatal capitalista.
} 
O Estado nacional europeu se revestiu da "violência do poder"6 (constituição de exércitos, seja de nacionais soberanos, que se efetivará com o absolutismo, seja com a contratação de mercenários) para alavancar a "violência do dinheiro", realizando-a pela via da expansão territorial, o que, em outras palavras, significou a própria expansão da influência econômica (principalmente da ampliação dos territórios tributáveis) e política (colônias, semicolônias, domínios e zonas de exploração): obteve-se a combinação sistemática do sistema colonial, o débito nacional, o moderno modo de taxação e o sistema protecionista (FIORI, 2012).

Desta feita, a expansão econômica (imposição da tributação) por via da guerra foi a atividade que marcou a invasão da África pelas potências europeias no século XV:

Quando os portugueses conquistaram Ceuta (1415) e deram início ao périplo africano, no contexto do mercantilismo, da formação dos Estados nacionais europeus e da constituição de um sistema mundial capitalista, os Estados africanos viviam seu próprio desenvolvimento (REIS DA SILVA, 2008, p. 97).

O sistema interestatal ocidental foi, num primeiro momento, alimentado pelas possibilidades econômicas que o controle político-administrativo de uma parte do continente africano (especialmente da costa ocidental) lhe proporciona. Não é sem razão que a posição de liderança internacional, naquele momento, estivesse nas mãos dos países que tomaram a iniciativa na ocupação de determinadas parcelas do continente africano, especialmente a península Ibérica7 ${ }^{7}$ Para tanto, a estratégia das metrópoles foi empregar o poder do Estado e a força concentrada e organizada da sociedade em favor do domínio político e econômico de novos territórios.

O capitalismo ibérico caracterizou-se por ser "politicamente orientado" (resultante de um processo sui generis, apontado pelo intérprete brasileiro Raymundo Faoro). Não apresentava as características que potencializariam a sua expansão, como

\footnotetext{
${ }^{6}$ Para Tilly (1996), a exposição ao fenômeno da guerra foi a variável-chave na formação dos Estados europeus modernos.

7 Segundo Raymundo Faoro (2001 [1958], p. 38): “As outorgas de atividades, dispersas e tímidas, ganham relevo com as grandes viagens, com os reis senhores incontestáveis dos mares e das rotas abertas na África, Ásia e América. O Estado torna-se uma empresa do príncipe, que intervém em tudo [...] Estão lançadas as bases do capitalismo de Estado, politicamente condicionado, que floresceria ideologicamente no mercantilismo".
} 
seria o caso do capitalismo holandês e do inglês ${ }^{8}$. No entanto, a rede comercial abastecida por Portugal e Espanha (que se estendia da Itália à Inglaterra) garantiu um destino rentável para os produtos saqueados da África e uma posição confortável para os “donos do poder" (FAORO, 2001).

Essas dinâmicas promoveram desestruturação/reestruturações na vida interna das sociedades africanas, com consequências tanto para o seu desenvolvimento interno quanto para a hierarquia do sistema internacional. A invasão da África, no século XV, instalou uma das lógicas centrais do sistema capitalista: a combinação da coerção, do desenvolvimento desigual e da dependência ao capitalismo nascente (REIS DA SILVA, 2008; TILLY, 1996).

De uma maneira geral, o resultado da expansão econômica e territorial sobre a África foi o fortalecimento dos Estados territoriais e das economias nacionais europeias, pois, a partir dessa estratégia, o Estado ibérico se articulava com o capital bancário (ciclo econômico genovês) para conseguir se financiar, dado que a extração de recursos via poder de tributação não era suficiente para manter as guerras de sobrevivência ou para ampliar o poder soberano de tributar povos e terras. Por outro lado, para os banqueiros italianos, essa estratégia produzia ganhos, pois, ao financiar o tomador de crédito (Estadonação), ampliava-se o poder dos financistas sobre a estrutura que exercia o poder de fato e que produzia regras e normas adequadas ao funcionamento de um sistema monetário e creditício em que os bancos passaram a "conquistar" privilégios bastante significativos. Esse processo combina força política e exploração econômica,

[...] a força é a parteira de toda sociedade velha grávida de uma nova. Ela própria é um poder econômico. A escravidão velada dos trabalhadores assalariados na Europa precisava, para seu pedestal, da escravidão pura e simples no novo mundo. 0 capital entra [no mundo] gotejando da cabeça aos pés, por cada poro, sangue e sujeira (MARX apud FRANK, 1980, p. 62).

Assim, a inserção internacional do continente africano no século XV ajuda a entender a dinâmica poder/dinheiro na formação do capitalismo e do sistema interestatal

\footnotetext{
8 Segundo Faoro (2001, p. 74): "O Estado se incha de servidores [...] O sistema não pode renovar-se, expandir-se, saindo das malhas dos enredos públicos, quer para incrementar a indústria, quer para se libertar da autofagia das suas organizações comerciais".
} 
moderno, uma vez que é possível entender o papel da guerra para a conquista dos territórios e a ampliação da capacidade financeira (de autofinanciamento e de financiar os demais atores sistêmicos) do Estado vencedor, o que lhe permite exercer a hegemonia no sistema (BRAUDEL, 1986; FIORI, 2012).

Desde o princípio do século XV até meados do século XIX, a inserção do continente africano nas relações interestatais, centralizadas na Europa, permitiu - a partir da conquista/domínio de regiões africanas - não apenas o controle de territórios tributáveis e a imposição de um sistema de regras, mas, sobretudo, a "detenção" do principal "produto" que o continente africano viu-se obrigado a fornecer às potências europeias: sua gente, seu suor ${ }^{9}$. A história da inserção africana no capitalismo comercial é a história do maior e mais longo genocídio da história humana: a escravidão dos povos africanos (WILLIAMS, 2012).

A exploração dos negros africanos era engrenagem fundamental de um dos principais elementos que permitiram tanto a ascensão das Províncias Unidas ${ }^{10}$ à hegemonia sistêmica quanto, principalmente, a ascensão da Inglaterra como hegemon sistêmico: o comércio marítimo triangular ${ }^{11}$. Esse comércio era extremamente lucrativo para as nações europeias, a ponto de que se argumenta que um dos pilares que permitiram à Inglaterra fazer a Revolução Industrial foi o acúmulo do capital escoado no e a partir do comércio marítimo triangular (que afluía pelo porto de Liverpool) ${ }^{12}$.

\footnotetext{
9 Marx trata esse ponto da seguinte maneira: "A transformação da África em uma reserva para a caça comercial dos peles-negras [...] assinalaram a rosada aurora da era de produção capitalista" (apud FRANK, 1980, p. 62).

10 No seu estágio comercial, que compreende os séculos XVI ao XVIII, a liderança foi inicialmente exercida pelas cidades italianas (Gênova, Florença e Veneza). A ascensão de Portugal e Espanha altera substancialmente a hegemonia sistêmica mediterrânea, principalmente, pela expansão territorial realizada no Atlântico com as grandes navegações e a descoberta do "Novo Mundo". Com as crises do mundo Ibérico, a hegemonia do sistema seria substituída pelas Províncias Unidas do Noroeste europeu, as cidades holandesas, cuja substituição, posteriormente, deu lugar ao aparecimento do ciclo hegemônico britânico.

110 comércio triangular é anterior à invasão da África e à descoberta da América. Entretanto, é a invasão da África e a descoberta da América que permitem acoplar os componentes que "aprimoraram" os ganhos comerciais: as plantations americanas, os produtos resultantes das plantations e a "mercadoria humana" (os escravos). Foi a incorporação do Novo Mundo e da África, no século XVI, ao sistema capitalista mercantil em expansão que expandiu e colocou o comércio triangular atlântico à frente do comércio triangular oriental (feito com os países asiáticos) (FRANK, 1980, p. 36).

${ }^{12}$ Eric Williams apud Frank (1980, p. 98) afirma: "Os lucros obtidos constituíram um dos principais fluxos desta acumulação de capital na Inglaterra que financiou a revolução industrial. 0 que a construção de navios para a transformação de escravos foi para a Liverpool do século XVII, a manufatura de produtos de algodão
} 
O principal nexo desse arranjo comercial, que configura a primeira divisão internacional do trabalho, foi o comércio europeu, que ficava com a maior parte do lucro da produção colonial em cada um dos vértices do comércio triangular. A África contribuía para o fenômeno da reexportação e resgate multilateral de pagamentos. Através do "triângulo escravagista", a Inglaterra enviava seus bens de consumo para a costa oeste da África e os escravos eram transportados através do Atlântico para a costa leste do Novo Mundo. Por sua vez, a manutenção do sistema de plantations e o baixo custo da mão de obra africana foram alimentados pelas colônias norte-americanas, que exportavam alimentos, animais vivos, madeira, etc. (FRANK, 1980).

A mão de obra escrava, provinda do continente africano, já era utilizada desde o século XV (plantations de açúcar no Mediterrâneo e nas ilhas do Atlântico, mesmo antes da descoberta da América), mas o recurso ao trabalho africano aumenta no século XVI e atinge proporções maiores durantes os séculos XVII, XVIII e primeira metade do século XIX. Estima-se que quase uma centena de milhões de africanos deixaram seus lares naquele continente. Desse modo:

[...] a África tornou-se uma parte integrante do desenvolvimento do capitalismo. Para suprir as economias de exportação, colonizadas e monocultoras, do Novo Mundo, com trabalho que produzia toda essa riqueza para a metrópole, a África também foi convertida em uma economia monocultura de exportação, e esse produto era o seu patrimônio mais precioso: os seus próprios habitantes, e dentre eles, os mais produtivos (FRANK, 1980, p. 42).

Desse modo, é possível argumentar pelo grande peso que o continente africano teve na hierarquia de poder internacional (e nas tendências cíclicas à guerra, na luta pela hegemonia e na competição pelo poder), pois o intercâmbio comercial (melhor dito, o intercâmbio desigual a que o continente africano fora submetido) - que dependia substancialmente de violência e de força física - garantia o ciclo de reexportação e pagamento multilateral e gerou um gigantesco fluxo de capital das colônias produtivas e exploradas para a metrópole. Esse acúmulo foi utilizado para o próprio desenvolvimento da metrópole (FRANK, 1980).

para compra de escravos foi para a Manchester do século XVIII. O estímulo inicial para o crescimento de monopólios de algodão veio dos mercados da África e das Índias Ocidentais". 
O capitalismo comercial (que, grosso modo, abrange o período de 1400 a 1800), no afã de transformar a África numa monocultura de exportação (suprir milhões de escravos para o desenvolvimento capitalista mundial), também transformou o modo de produção e organização (política e tribal) de extensas regiões africanas. Além da perda do potencial humano e de seu excedente econômico, o recrutamento de escravos no interior, através da guerra e do tráfico realizados por tribos costeiras, transformou a estrutura de classes e gerou o mútuo autointeresse econômico da metrópole e dos governantes locais na execução de uma política de subdesenvolvimento para a massa da população. Portanto,

The "triangular trade" that began with the seeking of slaves in Africa fulfilled this
essential function: the accumulation of money-capital in the ports of Europe as
the result of selling products of the periphery to members of ruling classes, who
were then stimulated to transform themselves from feudalists into agrarian
capitalists (AMIN, 1976, p. 156).

A competição dentro da hierarquia de poder internacional levou o capitalismo ao seu estágio industrial. A Grã-Bretanha começou a se desinteressar pela África enquanto fonte de escravos ${ }^{13}$, substituindo-a pelo crescente interesse pela África enquanto mercado para as manufaturas têxteis britânicas, o que estabeleceu as bases para a nova divisão internacional do trabalho, já sob a égide do capitalismo industrial, na segunda metade do século XIX ${ }^{14}$. A ênfase passou da procura de produtos estrangeiros para a procura de saídas para as manufaturas domésticas. Nesse momento, tem lugar o florescimento do "imperialismo" como luta competitiva pela hierarquia do poder internacional.

A abolição dos escravos não restaurou o mesmo status quo de dois séculos atrás no continente africano. A estrutura econômica e de classe da economia monocultora para exportação sobreviveu "necessariamente" à abolição. A monocultura de exportação de "gentes" fora substituída pela monocultura de exportação de azeite de dendê, de amendoim, de outras sementes oleaginosas, do cacau, etc. Ademais, o comércio foi administrado pelas principais companhias de comércio europeias (AMIN, 1976).

\footnotetext{
${ }^{13}$ Em 1807, o tráfico de escravos britânico foi formalmente proibido e os privilégios da East India Company foram severamente reduzidos.

14 Sobre o processo de incorporação na lógica da economia-mundo capitalista, ver: HOPKINS; WALLERSTEIN, 1987.
} 
Entretanto, a capacidade de ligar suas matérias-primas com as etapas de processamento - o que requeria equipamento necessário - não gerou uma acumulação interna de capital nem evitou sua drenagem para o exterior. 0 controle estrangeiro da comercialização de matérias-primas e, ainda mais, a posse estrangeira dos principais meios de produção limitaram

os potenciais efeitos difusores [...] limitou a expansão do processamento doméstico [...] desviou o investimento de capital e o fornecimento de infraestrutura para setores produtivos exportadores e [...] induziu a importação de bens que competiam para a produção doméstica (FRANK, 1986, p. 150).

Esse processo, que se prolongou da segunda metade do século XIX até 1945, polarizou as sociedades africanas e transformou sua economia rural. 0 desenvolvimento da produção para exportação provocou grandes movimentos intertribais e internacionais de trabalho migratório na África Ocidental. Do mesmo modo, o financiamento e a comercialização das safras de exportação estabeleceram a base socioeconômica para o desenvolvimento de uma burguesia rural africana (AMIN, 1976; FRANK, 1980).

No entanto, a principal característica que a nova inserção internacional do continente africano, dentro da luta hegemônica pela hierarquia do poder internacional, trouxe para o continente foi que a propriedade, antes tribal, foi transformada em propriedade privada pelos chefes tribais, que, por sua vez, as destinavam à produção de safras para exportação em seu próprio benefício.

A institucionalização da propriedade privada sob os privilégios dos chefes tribais (tradicionais e africanos) caracterizou e continua caracterizando as elites políticas africanas. No entanto, operacionalizar essa mudança significou, com a partilha da África (a partir da "maldição de Berlim ${ }^{15 ", ~ 1884-1885), ~ d e s t i t u i r ~ a s ~ p o p u l a c ̧ o ̃ e s ~ a f r i c a n a s ~}$ originais da posse comunitária da terra. Ao negar aos africanos o controle sobre os principais meios de produção, a metrópole europeia forçou uma mudança no modo de

\footnotetext{
${ }^{15}$ A maioria dos países africanos, até hoje, continua se ressentindo dos efeitos da Conferência de Berlim. Um exemplo desses efeitos é a contínua interferência das antigas potências colonizadoras em assuntos internos de suas ex-colônias, obrigando-as, por exemplo, em algumas circunstâncias, a assinar acordos militares que permitem, ainda hoje, uma presença militar estrangeira mais forte do que as forças do país ocupado, como o que na França se chamou de France-Afrique. Por isso, pode-se dizer que, até certo ponto, foi em Berlim que o continente africano começou a ser amaldiçoado.
} 
produção e na organização da sociedade, obrigando-os ${ }^{16}$ a participar do desenvolvimento de um novo modo de produção, no qual os colonos e a metrópole seriam os principais beneficiários, ou seja, assegurando trabalho barato para as minas e fazendas de exportação e o estabelecimento de uma elite local (muitas vezes tradicional e africana, a depender da parte do continente africano) que estivesse pactuada com as elites metropolitanas (FRANK, 1986).

0 processo pós-1945, que tem como principal característica a independência política da maioria dos países africanos e a realização de processos de industrialização ${ }^{17}$ (a doutrina do desenvolvimento, dentro da órbita da Guerra Fria) ${ }^{18}$, foi consolidado sobre as bases sociais, políticas e econômicas herdadas da divisão internacional do trabalho do período pós-1850.

As principais variáveis do desenvolvimento capitalista pós-1945 na África foram características não apenas do continente africano, mas, sim, da maioria das áreas subdesenvolvidas da economia-mundo capitalista: a concentração de terras, os salários reais controlados por mecanismos político-econômicos que asseguram a oferta desejada na taxa salarial desejada - a fim de garantir a superexploração da mão de obra local -, a dependência do financiamento e de tecnologia externa, o envio dos lucros para o centro capitalista e os padrões de cultura baseados na civilização norte-atlântica foram mantidos e aprofundados, caracterizando o desenvolvimento do subdesenvolvimento africano. No entanto, internacionalmente, esses "problemas de desenvolvimento interno" contribuíram - para não dizer que foram fundamentais - para o estabelecimento da hegemonia estadunidense no sistema mundial.

O diagnóstico da industrialização - ou da tentativa de industrialização - do continente africano revela que não é o "produto que define o produtor, mas sim o

\footnotetext{
${ }^{16}$ A "obrigação" resulta de um duplo movimento: o impedimento do camponês africano de se tornar um concorrente do fazendeiro ou proprietário de plantation europeu e o empobrecimento do campesinato africano a tal ponto que a maioria dos homens adultos fosse compelida a trabalhar para os europeus, nas minas ou nas fazendas (WODDIS apud FRANK, 1986, p. 196).

17 "This industrialization of the periphery occurred late in the day - between the two world wars, in the case of Latin America, and after 1945 in that of Asia and Africa" (AMIN, 1976, p. 209).

18 Para uma abordagem mais ampla, ver SAULL (2005).
} 
produtor que define o produto"19, ou seja, a divisão internacional do trabalho (pós-1945) muda, mas o princípio fundamental permanece o mesmo: a industrialização não elevou, nem qualitativa nem quantitativamente, os salários das populações africanas ${ }^{20}$. É nesse âmago que entra, substancialmente, a hierarquia de poder internacional:

É a natureza e a combinação específica das forças produtivas e das relações de produção dos países pobres no interior das relações capitalistas mundiais que constituem a base objetiva da pobreza de certos países dominados e que explicam os baixos salários e o consequente intercâmbio desigual (BETTELHEIM apud FRANK, 1986, p. 140).

Com o decorrer das décadas, que percorreram os movimentos de libertação nacional e os processos de desenvolvimento econômico, nos países africanos, o discurso sobre a nação, a modernização e a industrialização tornou-se cada vez mais apenas um discurso. 0 desenvolvimento econômico revelou-se, também, cada vez mais e tão somente crescimento econômico - quando havia crescimento! - e a emancipação nacional de facto ficava cada vez mais distante (AMIN, 2011).

Os acontecimentos dos anos 1970 (crise econômica mundial e crise de legitimidade política dos Estados Unidos) criaram as bases para um novo modelo de acumulação - a acumulação flexível ${ }^{21}$-, em que os processos de industrialização - que estavam dentro do pacto fordista dos anos 1940 - já não eram necessários para manter o Terceiro Mundo controlado pelo centro dinâmico capitalista. A "breve" integração da África no sistema mundial (1880-1960) teve seu fim.

Dos anos 1970 aos anos 2000, a África ficou à mercê do processo de mundialização do capital22. A exploração econômica foi aprofundada (realizada pelas tradicionais potenciais europeias e pelos Estados Unidos) e sua operacionalização ficou a cargo das multinacionais, que entraram para atuar, sobretudo, no setor primário (minérios, petróleo, comercialização dos produtos primários). 0 ajuste estrutural imposto

\footnotetext{
19 EMMANUEL apud FRANK (1986, p. 135).

20 SILVER (2005) trata o tema com pormenores.

21 Ver CHESNAIS (2010).

22 Os países africanos continuaram exercendo o papel de fornecedores de produtos agrícolas de baixo valor monetário, permitindo a redução do valor da força de trabalho nos setores capitalistas. Contudo, a partir das independências, o tipo de bem produzido passou a ser determinado pelo mercado (AMIN, 1977; AKYÜZ; GORE, 2001; KITCHING, 2000).
} 
pelas instituições financeiras internacionais como receituário para a crise da dívida 23 impôs às economias africanas a reprimarização ${ }^{24}$ dos países que haviam alcançado algum avanço "formal" no processo de industrialização (pois era das exportações primárias que se esperava prover os dividendos para o pagamento dos juros e serviços das dívidas). Portanto, os países desenvolvidos relegaram à África o status de "reserva potencial" para exploração do sistema interestatal capitalista (HOPKINS; WALLERSTEIN, 1987; AMIN, 2010).

A discussão ${ }^{25}$ sobre a hierarquia do poder internacional no sistema interestatal capitalista reascendeu com vigor nos entrantes anos 2000, do mesmo modo que a África reapareceu como importante continente para as estratégias e a competição entre as potências que buscam alcançar a hegemonia no sistema mundial. 0 ciclo econômico expansivo - a partir da ascensão chinesa - reintroduziu a África como um importante ator econômico, sobretudo pela estratégica capacidade de fornecer matérias-primas para os países desenvolvidos. Do mesmo modo, a ascensão econômica chinesa supõe novas preocupações político-militares, recolocando a África como importante cenário geoestratégico.

Portanto, conforme vimos, desde a constituição do sistema de Estados modernos e da economia-mundo capitalista, a África tem participado como importante elemento da configuração da hierarquia do poder internacional. Não houve hegemonia que relegasse o domínio e a exploração do continente africano a segundo plano! A geopolítica e a geoeconomia africanas mostram quão estratégico fora para as potências hegemônicas exercer o controle "inconteste" sobre o continente africano. Feito o recorrido da inserção internacional da África na definição da hierarquia do sistema interestatal capitalista, se procederá à análise de como os principais atores do sistema interestatal realizaram essa interação com o continente africano, de modo a caracterizar os "modelos" ou o modus

\footnotetext{
${ }^{23} \mathrm{Na}$ década de 1970, os grandes débitos africanos foram fortemente sentidos, chegando a representar $90 \%$ do PIB na África Subsaariana, o que engessou a economia (THOMSON, 2010).

${ }^{24}$ Hoje, 15 países africanos continuam tendo mais de 75\% de seu PIB dependente de apenas um produto, como é o caso da Argélia e do Burúndi (THOMSON, 2010).

${ }^{25}$ Questão levantada por autores como ARRIGHI (2008), ARRIGHI; SILVER (2012), WALLERESTEIN (2004), entre outros.
} 
operandi que tem sido empenhado sobre as gentes, os recursos e as esperanças dos povos africanos.

\section{OS MODELOS DE INSERÇÃO NO CONTINENTE AFRICANO:}

\section{uma África doador-dependente e refém dos modelos de desenvolvimento ocidentais}

Como vimos anteriormente, parece impossível discutir o desenvolvimento em África sem que se olhe para a "maldição de Berlim", que permitiu o retalhamento do continente entre as potências europeias. 0 auge dessa "maldição" foi a ocupação efetiva e a colonização dos povos africanos, o que de alguma maneira acabou condenando o continente ao atraso, relegado a uma figura de mero peão no sistema internacional. É que, mesmo com o advento das independências, a "maldição de Berlim" continua provocando uma série de instabilidades ${ }^{26}$ que não permitiram que países africanos vislumbrassem um rumo de sucesso tal como, por exemplo, aconteceu com países de outras regiões que vivenciaram uma experiência similar, como a China, a Índia, a Coreia do Sul, na Ásia, e Argentina, Brasil e México, na América Latina, que lograram sucesso ao longo do tempo, o que lhes permite, hoje em dia, disputar espaço no sistema internacional com os atores tradicionais em igualdade de circunstância.

Para Amsden (2009), a ascensão desses países foi uma das mudanças fenomenais da segunda metade do século XX. Mas, quando olhamos para a realidade africana, verificamos que, até a segunda década do século XXI, não se tem nenhum país que se possa considerar um ator em condições de competir em igualdade de circunstâncias quer com os atores considerados emergentes, quer com os atores tradicionais. Ainda se pode pensar, por exemplo, na África do Sul nos Brics, como digno representante dos países

\footnotetext{
${ }^{26}$ Ngoenha (2011) defende a ideia de que o continente africano vem sofrendo instabilidades porque muitas potências coloniais foram obrigadas a ceder as independências sem estar convencidas do bem fundado das reivindicações do direito à autodeterminação por parte dos povos africanos. A reação dessas potências foi bastante dura, utilizando de todos os meios e estratégias para impedir o acesso das colônias à liberdade. Algumas das estratégias foram as guerras e/ou a transformação das colônias em territórios ultramarinos, o exemplo seguido por Portugal em relação a Moçambique, Angola, Guiné-Bissau, São Tomé e Príncipe e Cabo Verde. No entanto, os países que negaram essa estratégia neocolonial sofreram retaliações, como é o caso da Guiné de Sékou Touré; outros foram obrigados a assinar acordos militares que permitem, ainda hoje, uma presença militar estrangeira mais forte do que as forças do país ocupado, o que na França se chamou France-Afrique.
} 
africanos. Porém, se analisarmos com certa profundeza a inserção desse país nos Brics, é fácil entender que se trata, apenas, de uma presença meramente estratégica para os outros países que compõem o grupo, isto é, a África do Sul aparece para colmatar a ausência de um país africano no grupo, uma vez que este já congregava um representante da América, um da Eurásia e dois da Ásia, os quais, na verdade, são economias muito mais robustas se comparadas à do "representante africano"27. Inclusive, a África do Sul, em algum momento, é criticada por outros Estados africanos pelo fato de agir como portavoz dos africanos sem que, necessariamente, esteja a promover interesses do continente (ADEBAJO, 2013, p. 69).

O mais significativo a assinalar é que, como aponta Ngoenha (2014), depois das independências africanas, certos países optaram por economias planificadas, outros por modelos de desenvolvimento autocentrado, outros fizeram programas de promoção das exportações, outros privilegiaram o desenvolvimento de um setor do Estado, outros aderiram aos programas de ajustamento estrutural e por aí em diante, mas o resultado mantém-se o mesmo: insucesso. Algumas questões se podem colocar em relação a essa situação: o que torna os países africanos incapazes de marchar ao mesmo ritmo que países de outros continentes que experimentaram um passado similar ao dos africanos? São a Europa e os EUA a cura para os problemas da África?

Parece que a resposta a essas questões pode ser encontrada na gênese das independências dos países africanos e na situação política internacional que se vivia àquela altura (Guerra Fria). Embora a maioria desses países tenha adotado a política de "não alinhamento" ao bloco ideológico Leste-Oeste, essa situação não os isentou de desenvolver relações privilegiadas (mesmo não sendo estáveis) com uma ou outra superpotência. Isso permitiu que os Estados africanos continuassem a solicitar, e a receber, apoios financeiros e políticos importantes com base na sua lealdade no conflito entre as superpotências (OLIVEIRA, 2009).

\footnotetext{
27Importa sublinhar que a África do Sul não é a maior economia da África, o que a torna, no grupo, apenas um elemento de representação geográfica, mais uma vez para justificar a importância do continente africano na definição da hierarquia de poder no sistema internacional, assim como a representatividade, à escala mundial, dos Brics.
} 
Na verdade, essa passou a ser a característica da inserção da África na economia mundial. Mas, com o fim da Guerra Fria, inaugura-se uma nova fase, "menos generosa e previsível, em que os frutos recentes do processo de extroversão - respeito pela soberania e recursos financeiros na forma de apoios para o desenvolvimento ou de assistência militar - já não eram dados adquiridos (OLIVEIRA, 2009, p. 100)”. Em contrapartida, governantes corruptos e autoritários, como Mobutu, do Zaire, e Samuel Doe, da Libéria, continuaram a encontrar sustento exterior e proteção dos seus antigos colonizadores nas instituições financeiras internacionais, que, de forma irresponsável, emprestam bilhões de dólares sem garantia de pagamento desse débito, tornando seus países eternos devedores dessas instituições (ADEBAJO, 2013).

A partir daí, novas exigências para o acesso ao crédito pelos países africanos são colocadas, tendo como a face mais visível o Banco Mundial e o Fundo Monetário Internacional, que impuseram um ajustamento estrutural, sem ter em conta as especificidades e necessidades reais dos povos africanos. Como corolário, essa medida resultou em fracasso, produzindo efeitos desestabilizadores sobre as sociedades africanas, como assinala, por exemplo, Harrison (2004). Essa situação foi também acompanhada por aquilo que Adebajo (2013) designou como global apartheid ${ }^{28}$, promovido pela ONU. Para o autor, o global apartheid causa, na maioria da população do mundo (em particular, do Terceiro Mundo), sofrimento e piores formas de opressão e injustiças como resultado, em parte, da estrutura global do poder político e social. E o ponto crítico dessa situação, particularmente para a relação África-ONU, é o fato de a ONU, apesar de ter sido criada sob o escopo de justiça e igualdade, na sua estrutura, possuir um conselho de segurança capaz de manipulá-la em desvantagens para a África, o que torna cada vez mais uma miragem a saída dos países africanos da condição de pobreza.

0 resultado disso é a crônica dependência, por parte dos países africanos, dos doadores e a prisão aos modelos transplantados da Europa e dos EUA, que pouco contribuem para o desenvolvimento do continente. Como Moyo (2009) sublinha, a África

\footnotetext{
${ }^{28}$ Global apartheid descreve as desigualdades política e socioeconômica que existem entre os países ricos e industrializados do hemisfério Norte e os países pobres do hemisfério Sul.
} 
vive uma "cultura de ajuda", na qual aqueles que estão em melhor situação comungam tanto mental como financeiramente - da ideia de que dar esmolas aos os pobres (África) é a coisa certa a fazer. Fazem os africanos acreditarem que "the rich should help poor, and the form of this help should be aid". A ideia de "ajuda" para o continente infesta até a indústria de entretenimento:

In the past decade alone, on the back of Live 8, Make Poverty History, the Millennium Development Goals, the Millennium Challenge Account, the Africa Commission, and the 2005 G7 meeting (to name a few), millions of dollars each year have been raised in richer countries to support charities working for Africa (MOYO, 2009, p. xix).

A autora estima que, em mais de 50 anos, mais de 1 trilhão de dólares em ajuda relacionada com o desenvolvimento foram transferidos para a África pelos países desenvolvidos, mas esse valor quase em nada contribuiu para diminuir o subdesenvolvimento. Pelo contrário, a "ajuda" ajudou a tornar os pobres mais pobres e a crescerem lentamente. A miséria e a pobreza não acabaram; pelo contrário, aumentaram:

E, enquanto o número de população e a proporção de pessoas no mundo vivendo em extrema pobreza caíram depois de 1980, a proporção de pessoas, na África Subsaariana, que vivem em extrema pobreza aumentou para quase 50 por cento. Entre 1981 e 2002, o número de pessoas no continente que vivem na pobreza quase dobrou, deixando a média de africanos mais pobres hoje do que há duas décadas. E, olhando para a frente, o relatório de 2007 das Nações Unidas para o desenvolvimento humano prevê que a África Subsaariana será responsável por quase um terço da pobreza mundial em 2015, contra um quinto em 1990 (este em grande parte devido aos avanços dramáticos no desenvolvimento sendo feitos em outros lugares ao redor do mundo emergente) (MOYO, 2009, p. $5)$.

Essa situação, na verdade, mostra que o modelo ocidental não está contribuindo para o desenvolvimento, pois atrofia a possibilidade de os próprios países africanos desenvolverem iniciativas que lhes permitam criar modelos próprios. É que, para além de o modelo de ajuda do Ocidente e dos EUA não se adequar às características específicas das sociedades africanas, também é acompanhado por condicionalidades que não permitem que os governantes dos países africanos direcionem essas ajudas de acordo com as necessidades de seus países. 
É exatamente nesse ponto que está outra questão importante, que é a entrada em cena de novos atores internacionais na "disputa": os países economicamente em crescimento (China, Índia, Brasil, Rússia, entre outros), que vêm acirrando cada vez mais a discussão sobre o futuro da África no cenário internacional. Serão esses países uma solução para uma inserção digna da África no plano global?

O primeiro elemento que parece importante abordar é a existência de uma aparente clivagem entre os atores tradicionais de cooperação com a África e os emergentes. 0 principal ponto de discórdia assenta-se na forma como cada grupo de atores libera as ajudas para o continente. Enquanto os atores tradicionais impõem condições para liberar a ajuda para a África, os emergentes não as impõem, resultando daí críticas aos últimos. A principal crítica é que os emergentes não estão tendo em conta a pressão que o Ocidente tem feito sobre os Estados africanos para melhorarem a proteção dos direitos humanos e a governação. A resposta dos emergentes é que o que guia as relações desses países com a África são necessidades econômicas e políticas sob a retórica de benefícios mútuos e a não interferência nos assuntos internos dos Estados africanos (SAUTMAN; HAIRONG, 2006; TULL, 2009).

Num primeiro momento, vemos as divergências entre esse grupo de atores de cooperação como positivas, na medida em que seria esse o momento em que os países africanos poderiam inverter a situação, passando, eles mesmos, a impor as modalidades de cooperação com esse grupo de países. Nesse caso, consideramos a possibilidade de os africanos optarem por um ou pelo outro, ou, ainda, pelos dois, o que seria um caminho para que passassem a traçar modelos próprios de desenvolvimento, que se ajustassem às necessidades de seus países sem que se vissem a cumprir medidas totalmente desajustados à realidade sua e de seus povos. Isso entraria no espírito do que Ngoenha (2014) defende, que é a necessidade de todas as transformações emanarem das escolhas coletivas (nesse caso, seria o imaginário social e dos componentes simbólicos da cultura dos povos africanos), pois "somos nós que conhecemos os meios adequados para o nosso desenvolvimento".

Num outro momento, a disputa entre esses grandes grupos não tem em vista, apenas, "expansão" dos seus interesses no continente. É indubitável que essas novas 
potências tenham interesse em assumir um papel de destaque no plano internacional. Nesse sentido, a África pode servir para a promoção da ideia de que esses países podem constituir, na política mundial, uma alternativa às potências tradicionais. Ademais, é necessário realçar que alguns desses países emergentes têm interesses que convergem para os dos atores tradicionais e divergem muito dos interesses dos países africanos, mas também essa disputa pode conduzir os países africanos a uma situação de "quem paga mais fica com tudo", que poderia perpetuar outros fenômenos, como a corrupção e a exclusão social, ou ainda a um "vale-tudo", que pode ressuscitar fantasmas vividos durante o mundo bipolar.

Resumidamente, queremos dizer que a África, até algumas décadas atrás, era vista no sistema internacional como dependente da ajuda externa (particularmente da Europa e dos EUA) e refém dos modelos de desenvolvimento ocidentais, o que a configurava, apenas, como um "peão". Com o fim da Guerra Fria e a consequente ascensão de novas potências mundiais, a África ganha uma nova dimensão, na medida em que virou um espaço fértil para a disputa e a afirmação entre essas potências e as potências tradicionais, podendo, a depender da forma como as diferentes lideranças africanas articularem, passar de "peão" para ator importante.

\section{CONSIDERAÇÕES FINAIS}

Neste artigo, procuramos demonstrar que o continente africano foi e continua sendo uma importante peça na definição e configuração da hierarquia de poder do sistema internacional. Ao longo dos anos, tem sido praxe que os países que disputam a hegemonia sistêmica procurem ampliar sua influência econômica, política e cultural sobre a sociedade africana. 0 continente africano foi o locus do duplo movimento de demonstração e criação de capabilities para os Estados do centro sistêmico. Para efetivar essa ação, os países centrais ampliaram os mecanismos de exploração, dominação e hegemonia, na maioria das vezes, pactuando com as elites locais, forjadas na imposição do processo de divisão internacional do trabalho.

Se, por um lado, é verdade que não se pode dissimular a responsabilidade das elites dirigentes locais, que, sobretudo após as independências, optaram por determinado 
modelo de "desenvolvimento", tampouco é certo atribuir somente a elas essa escolha. A nacionalização (pelos processos de estabelecimento, pelo menos do ponto de vista formal, do Estado-Nação) dos centros de decisão, apesar de tarefa necessária no caminho da busca pela autonomia decisória, é elemento insuficiente para avaliar o real processo de interiorização das decisões. E, mais além, o processo de interiorização das decisões pressuporia uma elite comprometida com o destino nacional e não apenas com o fortalecimento do seu próprio privilégio, com a ampliação de sua propriedade e com o afã de tornar-se, cada vez mais, exclusiva e exclusivista dona do poder, dona dos Estados africanos.

A dicotomia escolha/imposição de modelos de desenvolvimento é falsa. A escolha nacional, ao longo dos anos, foi apenas uma "miragem retórica" que as potências tradicionais encontraram para atribuir a culpa das mazelas africanas às elites locais - e ao mesmo parecer de que isso é resultado da autodeterminação. A escolha teria de pressupor possibilidade de negação e, como tratamos no artigo, a possibilidade de negar a injusta e desigual divisão internacional do trabalho, que não tem sido apresentada como uma opção ao continente africano.

Mesmo os "novos modelos" que as potências emergentes dizem estar aplicando no continente africano são limitados em seu alcance para transformar o papel dos países africanos na divisão internacional do trabalho. Políticas como a "cooperação técnica", o "perdão de dívidas", entre outras - a despeito de apresentarem características novas -, não trazem grandes mudanças com relação à sua principal lógica: uma das faces da hegemonia é a percepção (por parte do dominado) de que os dois lados (África e países emergentes) estão colhendo frutos positivos da inserção internacional no continente africano.

No entanto, ou os "frutos positivos" da ação dos países emergentes ainda estão maturando (esse é sempre um argumento possível), ou os resultados com os quais deparamos não permitem chegar a uma conclusão sobre os resultados benéficos para as gentes africanas, a julgar: i) pela não alteração do quadro estratégico de ação das elites econômicas, políticas e culturais africanas; ii) pelo não questionamento da participação africana na divisão internacional do trabalho exclusivamente como exportador de 
produtos primários; e iii) por confundir "consumo", permitido pelo aumento dos ingressos das exportações, o que trouxe a possibilidade de ampliar importações principalmente chinesas -, com a realização da cidadania.

É óbvio que, em países com pobreza extrema e subdesenvolvidos, como é o caso da maioria dos países da África, aos quais sempre foi imposto um modelo de superexploração massiva de sua gente e negação dos elementos básicos do capitalismo que caracterizam os "modelos de desenvolvimento", sobretudo o direito ao trabalho, a democratização da propriedade, a democratização do poder, a democratização do prestígio social -, permitir o acesso da população ao consumo é algo substancialmente importante, e isso não se busca aqui negar.

As aquisições materiais são parte do imaginário e do direito à cidadania. Agora, outra coisa é resumir a cidadania em si às aquisições materiais, apenas ao incremento do consumo. Em tempos em que o capitalismo financeiro amplia enormemente seus lucros, as políticas de distribuição de renda (uma espécie de serviço social das altas finanças) que possibilitam o consumo parecem tão somente direcionadas para amortecer o impacto da gigante e crescente desigualdade que prevalece na maior parte do mundo e, especialmente, no continente africano. Mais realista do que cômico, Nelson Rodrigues acertou na mosca quando alertou: "Subdesenvolvimento não se improvisa; é obra de séculos".

\section{REFERÊNCIA BIBLIOGRÁFICA}

ADEBAJO, A. The Curse of Berlin. Columbia University Press. New York, 2013.

AKYÜZ, Y.; GORE,C. African economic development in a comparative perspective. Cambridge Journal of Economics, v. 25, p. 265-288, 2001.

AMIN, S. Unequal Development: an essay on the social formations of peripheral capitalism. England: The Harvester Press, 1976.

AMIN, S. A África hoje - na visão de Samir Amin. Comunicação \& Política, n.s., v.VII, n.2, p. 067-173, 2011. 
AMIN, S. África: conflictos, oportunidades y desafíos de refundación. La Habana: Cuadernos de Pensamiento Crítico No. 6, 2010.

AMIN, S. O Capitalismo e a renda fundiária. In: A Questão agrária e o capitalismo. RJ: Paz e Terra, 1977.

ARRIGHI, G. Adam Smith em Pequim. SP: Boitempo, 2008.

ARRIHI, G.; SILVER, B. 0 fim do longo século XX In: FILOMENO, Felipe A et al. O Brasil e o capitalismo histórico. SP: Cultura Acadêmica, 2012.

BARRACLOUGH, G. Introdução à História Contemporânea. 3a Edição. Zahar Editores. Rio de Janeiro, 1975.

BRAUDEL, F. La dinámica del capitalismo. México: Fondo de Cultura Económica, 1986.

CHESNAIS, F. Prefácio In: MARQUES, R. M (org.). O Brasil sob a nova ordem: a economia brasileira contemporânea. SP: Saraiva, 2010, pp. IX-XV.

FAORO, R [1958]. Os donos do poder. 3 ed. RJ: Editora Globo, 2001.

FIORI, J. L. No princípio era Portugal. Carta Maior, 26 set. 2012. Disponível em: < http://migre.me/reXPo>. Acesso em: 05 abr. 2015.

FRANK, A. G. Acumulação dependente e subdesenvolvimento: repensando a teoria da dependência. SP: Editora Brasiliense, 1980.

FRIEDEN, Jeffry A. Capitalismo Global: História Econômica e Política do Século XX. Zahar Editores, Rio de Janeiro, 2006.

HARRISON, G. The World Bank and Africa. Routledge. Lond and New York, 2004.

HOPKINS, T.; WALLERSTEIN, I. Capitalism and the incorporation of new zones into the World-economy. Review, X, n. 5/6, p. 763-779, 1987.

KITCHING, G. Why I gave up African studies. African Studies Review \& Newsletter, v. 22, n. 1, p. 21-26, June 2000.

MOYO, D. Dead Aid: Why Aid Is Not Working and How There Is a Better Way for Africa. Farrar, Straux \& Giroux; New York, 2009. 
NGOENHA, Severino. Intercultura, alternativa à governação biopolítica? PubliFLX. Maputo. Dezembro de 2013.

. Das Independências às Liberdades: Filosofia Africana. Editora Paulinas, Maputo, 2014.

OLIVEIRA, Ricardo Soares de. A África desde o fim da Guerra Fria. Revista de Relações Internacionais, no 24. Dezembro: 2009, [p. 93-114]

REIS DA SILVA, André L. Os Estados Africanos nos séculos XVI-XVIII In: MACEDO, José Rivair (org.) Desvendando a história da África. Porto Alegre: Editoria UFRGS, 2008, pp. 97-111.

SAULL, R. Locating the Global South in the Theorisation of the Cold War. Third World Quartely, v.26, n.2, pp. 253-280, 2005.

SAUTMAN, B; HAIRONG, Y. Honour and shame? China's Africa ties in comparative context In WILD, L; MEPHAM, D. The New Sinosphere: China in Africa. IPPR, 2006.

SILVER, B. J. Forças do trabalho: movimentos de trabalhadores e globalização desde 1870. SP: Boitempo, 2005.

THOMPSON, A. An Introduction to African Politics. Nova Iorque: Routledge, 2010.

TILLY, C. Coerção, Capital e Estados Europeus. SP: Edusp, 1996.

TULL, D. M. China's Engagement in Africa: Scope, significance, and consequences In HARBEGSON, R. C. Africa in world politics. Boulder: Westriew Press, 2009

WALLERSTEIN, I. O declínio do poder americano. RJ: Contraponto, 2004.

WALTZ, K. Theory of International Politics. Reading: Addison-Wesley, 1979.

WILLIAMS, E. Capitalismo e Escravidão. SP: Companhia 